A Foot Sensor using Multiple Independent Force Sensors for Compact-sized Humanoid Robots

O Shimomura M.(JST), Shimizu M.(JST), Endo K.(JST/Keio Univ.), Furuta T.(JST), Okumura Y.(JST), Tawara T.(JST), Kitano H.(Sony CSL/JST/Keio Univ.)

本研究では，2足歩行口ボットが人間の住む寋環境に対応し，安定した歩行を行うために必要な足裏セ ンサの開発を目指す. 本開発センサは足底を 4 つに分割することにより，足側面の接地状況を判断する事 ができる.

1P1-3F-B5＼cjkstart柔軟接触センサによる滑り検出について

○濟藤 直樹 (秋田県立大), 梶川伸哉 (秋田県立大), 岡野 秀晴 (秋田県立大) Slip Detecting by the Flexible Structural Tactile Sensor

Saito N.(Akita Prefectural Univ.) Kajikawa S.(Akita Prefectural Univ.), Okano H.(Akita Prefectural Univ.) 柔軟構造を有する接触位置と接触力を計測するセンサを物体把持動作に適用することを目的として，物体 とセンサ間に発生する滑り検出実験を行った結果を示し，本センサの滑り検出に関する可能性を示唆する.

1P1-3F-B6＼cjkstart複数の触覚を持つ柔軟指の製作

O山崎 雄介 (阪大), 多田 泰徳 (阪大), 細田 耕 (阪大/阪大 FRC), 浅田 稔(阪大/阪大 FRC)

Development of a Soft Finger with Multiple Tactile Sensors

Yamasaki Y.(Osaka Univ.), Tada Y.(Osaka Univ.),

Hosoda K.(Osaka Univ./HANDAI FRC), Asada M.(Osaka Univ./HANDAI FRC)

本研究では歪ゲージとピエゾ素子を触覚センサとして持っ柔軟指を製作し，双方の特性の違いによって， 材質やすべり方についてより詳細な情報が得られることを示す。

1P1-3F-B7 光変化を用いたロボット指用接触覚センサに関する研究

Tactile Sensor for Robotic Digits Applying Light Scattering Detection

O大西 謙吾 (大分大), 北村 亮二 (大分大), 宮川 浩臣 (大分大)

O Ohnishi K.(Oita Univ.), Kitamura R.(Oita Univ.), Miyagawa H.(Oita Univ.) 柔軟物のハンドリングを目的としたロボット指先用接触覚センサの開発を進めた. 物体の接触に伴い生 じる散乱反射をパターン状に配置した光学式センサで検知する方法を用いた。このセンサの製作と基礎実 験を行った。

1P1-3F-C1＼cjkstart触覚における皮に膚構造の役割

The Role of Skin Structure in Human Tactile Sensing

○传藤 尚 (東大), 梶本 裕之 (東大), 舘 暲 (東大)

O Sato T.(The Univ. of Tokyo), Kajimoto H.(The Univ. of Tokyo) Tachi S.(The Univ. of Tokyo)

皮膚表面态力が機械受容器に至るまでに，指紋や乳頭といった皮膚構造によって受ける処理を有限要素 法により解析した。 その結果, 応力方向の違いがひずみの空間分布に変換され，機械受容器群の発火頻度 比にコーディングされる可能性を示した.

\title{
○人間機械協調 2
}

1P1-3F-C2 VR 技術を導入したマスタ・スレーブシステムによる人間機械協調作業

一表面形状認知作業への店用一

○磯部 陽一 (名大), 嶋田 宏史 (名大), 鈴木 達也 (名大), 早川 聡一郎 (豊画厂大) 大熊 繁 (名大), 藤原 文治 (名大)

Man-Machine Cooperation by Master-Slave System Using VR Technology -Application to Recognition of Surface Shape-

O Isobe Y.(Nagoya Univ.), Shimada H.(Nagoya Univ.), Suzuki T.(Nagoya Univ.), Hayakawa S.(Toyota Technological Inst.) Okuma S.(Nagoya Univ.), Fujiwara F.(Nagoya Univ.) 仮想環境下で作業するオペレータと，ある程度の自律性を持たせたロボットとの協調を考慮に入れたマ スタ・スレーブシステムを提案する。また，提案システムを物体表面の形状認知作業一忘用し，実験を通し てその有効性を検証する。

1P1-3F-C3 人間とロボットの共通認知モデルを介したアクティブタッチの模倣システム

○昆陽雅闰 (神戸大), 田所諭 (神户大), 糀 幸久 (神戸大), 徳田 献一(神严大) 高森年 (神户大)

Active Touch Imitation System through Common Cognitive Models of Human and Robots

O Konyo M.(Kobe Univ.), Tadokoro S.(Kobe Univ.), Koji Y.(Kobe Univ.) Tokuda K.(Kobe Univ.), Takamori T.(Kobe Univ.) 
ロボットアームを用いて人間の能動的な触運動を模倣するシステムを構築寸る。人間とロボットに共通 する認知モデルを用いて，感覚と運動が統合された特徵量を自己組織的に抽出し，運動を生成する方法を 提案する.

\section{P1-3F-C4 RoBE を用いたモバイルマニピュレータの実時間自己衝突回避制御}

一第 1 報 几長自由度を用いた自己衝突回避動作一

○瀬卧文美 (東北大), 小悺一弘 (東北大), 須田 理央 (東北大), 平田 泰久 (東北大/科技団さきがけ)

Real-Time Control of Self-collision Avoidance for Mobile Manipulator using RoBE -Self-collision avoidance motion using redundancy-

Seto F.(Tohoku Univ.), Kosuge K.(Tohoku Univ.), Suda R.(Tohoku Univ.), Hirata Y.(Tohoku Univ./PRESTO JST)

RoBE という弾性要素を用いる手法でロボット形状を表現し，その反力を用いたモバイルマニピュレー 夕における実時間自己衝突制衙を提案，双腕型移動ロボット”MR Helper”に実装して，その有効性を検証 する.

\section{P1-3F-C5 人間共存ロボットの觝触適応行動}

一第 12 報：触覚機能を備えた肘関節の試作一

岩田浩康 (早稻田大), ○亀村隆史 (早稲田大), 菅野重樹 (早稻田大)

Physical Interference(PIF) Adapting Behaviors in Human Symbiotic Robots

-A development of elbow joint with tactile perception-

Iwata H.(Waseda Univ.), O Kamemura T.(Waseda Univ.),

Sugano S.(Waseda Univ.)

ロボットが人閒との物理的触れ合い（觝触）状況を理解するためには，全身での触覚機能が必要である。 本稿では，2軸連動機構とカバーセンサ構造により，関節可動部での触覚機能を寒現可能な肘関節 1 自由 度アームの開発について述べる.

\section{P1-3F-C6 Linux による半自律ロボットの操作支援}

一地図生成インターフェースの構築一

○四代正人 (九I大), 大塚博道 (九工大), 浅海 賢一 (九工大), 喜多村 直 (九工大)

Operation Support of Semi-autonomous Mobile Robot by Linux

-Construction of remote map generation interface-

Tashiro M.(Kyushu Inst. of Technology), Otsuka H.(Kyushu Inst. of Technology), Asami K.(Kyushu Inst. of Technology),

Kitamura T.(Kyushu Inst. of Technology)

移動口ボットが人閒と協調して単純作業を実施するために環境認識のための地図の自動描画機能を加え, 最小限の人間の補助によって目的地到達や障害物回避を行うためのインターフェースの開発を行った。

1P1-3F-C7 自律遠隔融合制御の高度化

The Advancement of Autonomous and Remote Fusion Control

○杉浦篤 (名城大), 團 良鿆 (名城大), 大道武生 (名城大) Sugiura A.(Meijo Univ.), Dan R.(Meijo Univ.), Oomichi T.(Meijo Univ.) 人間とロボットがそれぞれ得意な作業をロボットの判断で分担する自律遠隔融合制御の有効性を例証. A G Vが末知物体に遭遇するなど不測の事態に宿った時に，簡素な画像技術を使ってA G Vに目標を教示 し, 運行信賴性を向上させる.

1P1-3F-C8

人間一ロボット協調作業系におけるインピーダンス制御システムの安定性の解析

一人閶の反态時間の遅孔およびロボットのコンプライアンスを考慮した解析方法の提案—

○㴊上康徳 (同志社大), 䅡際 徽 (闹志社大), 横川隆一 (同志社大), 原 敬 (同志社大)

Stability Analysis for Impedance Control System in Human-Robot Cooperative Task System

-Analysis method as regards time delay of human movement and compliance of robot-

Fuchikami Y.(Doshisha Univ.), Tsumıgiwa T.(Doshisha Univ.), Yokogawa R.(Doshisha Univ.), Hara K.(Doshisha Univ.)

インピーダンス版御では接触条件によってシステムが不安定になることが知られている。そこで，人間 の反灾時閒の遅れ，および，ロボットのコンプライアンスを考慮した協調作業系におけるシステムの安定 性の解析方法を提案する。

1P1-3F-D1 3 次元計測装置 OPTOTRAK3020を用いた運動中における人間の上肢関節トルク計測 システムの構築

一人閒とロボットの協調作業にお打る人間の運動の定量的評価法の提案一 